\title{
Obsidian geochemistry, geoarchaeology, and lithic technology in northwestern Patagonia (Argentina)
}

\author{
M. Victoria Fernández ${ }^{\mathrm{a}}$, Ramiro Barberena ${ }^{\mathrm{b}}$, Agustina A. Rughini ${ }^{\mathrm{c}}$, Martín Giesso ${ }^{\mathrm{d}}$, \\ Valeria Cortegoso ${ }^{b}$, Víctor Durán ${ }^{\mathrm{b}}$, Guadalupe Romero Villanueva ${ }^{\mathrm{e}}$, Karen Borrazzo ${ }^{\mathrm{f}}$, \\ Gustavo Lucero $^{\mathrm{g}}$, Raven Garvey ${ }^{\mathrm{h}}$, Brandi Lee MacDonald ${ }^{\mathrm{i}}$ and Michael D. Glascock ${ }^{\mathrm{i}}$
}

\section{ABSTRACT}

We studied the organization of mobility of hunter-gatherers groups of northwestern Patagonia (Argentina) from an interdisciplinary perspective. We combined geochemical and technological characterization of obsidian assemblages from surface and stratigraphic contexts spanning the Holocene, and a preliminary geoarchaeological study of the sources. The goals were to assess the provenance, mode of supply, use, and discard of obsidian artifacts on the basis of information on the structure of the two main regional sources: Cerro Huenul, located in the lowlands, and Laguna del Maule, located in the Andean highlands. We conducted geoarchaeological field sampling at different altitudes of the Barrancas River fluvial deposits to study the geomorphic impact on the secondary structure of the highland source. Preliminary geoarcheological results allow extending the area of availability up to $90 \mathrm{~km}$ towards the lowlands from the outcrops. In addition, we performed non-destructive XRF analyses on 266 lithic artifacts, which were placed along a continuum of reduction. $89 \%$ of the artifacts corresponded to the local Cerro Huenul source, while $11 \%$ to Laguna del Maule. While the artifacts made on Cerro Huenul obsidian were represented by the full reduction sequence, those from

\footnotetext{
${ }^{a}$ CONICET, IIDyPCa, Universidad Nacional de Río Negro, San Carlos de Bariloche, Argentina.Email:fernandezvicky5@gmail.com

${ }^{b}$ CONICET, Laboratorio de Paleoecología Humana. Facultad de Ciencias Exactas y Naturales, Universidad Nacional de Cuyo. Mendoza, Argentina.

${ }^{c}$ Facultad de Filosofia y Letras, Universidad de Buenos Aires. Buenos Aires, Argentina.

${ }^{\mathrm{d}}$ Northeastern Illinois University, Department of Anthropology. Chicago, USA.

${ }^{e}$ CONICET, Instituto Nacional de Antropología y Pensamiento Latinoamericano. Buenos Aires, Argentina.

${ }^{f}$ CONICET, IMHICIHU. Facultad de Filosofia y Letras, Universidad de Buenos Aires. Buenos Aires, Argentina.

${ }^{\mathrm{g}}$ Laboratorio de Paleoecología Humana. Facultad de Ciencias Exactas y Naturales, Universidad Nacional de Cuyo. Mendoza, Argentina.

${ }^{h}$ Department of Anthropology, University of Michigan, USA.

${ }^{i}$ Archaeometry Laboratory, Research Reactor Center, University of Missouri, Columbia, USA.
} 
Laguna del Maule are only represented by advanced stages. We integrate these results with information on the frequencies of projectile points, ceramics, and rock-art motifs for the two main archaeological sites in the region: Cueva Huenul 1 and Cueva Yagui. These proxies indicate that the sites have different place use histories, providing a scheme for the analysis of human use of the regional landscape.

Keywords: Obsidian Geochemistry; Patagonia; Lithic Technology; Geoarchaeology; Organization of mobility.

\section{Introduction: goals and research frame}

Spatial organization in mobile societies is a multi-layered phenomenon connecting diverse socio-economic spheres (e.g., Binford, 1980; Kelly, 1995; Marlowe, 2005). An approach to the organization of mobility that combines the geochemical characterization of lithic raw material sources and technological patterns is optimally suited to tackle this issue on an archaeological scale (Jones et al., 2003; Surovell, 2009). Due to its compositional homogeneity, obsidian can be thoroughly characterized using diverse geochemical methods (Glascock, 2002; Shackley, 2005; Rademaker et al., 2013). Geological and geochemical data from available lithic sources provide the frame of reference to assess the provenance of the lithic raw materials of archaeological artifacts. In turn, this allows the assessment of patterns of human mobility, resource provisioning, and the existence of indirect mechanisms involved in raw material acquisition (Hughes, 1998; Kelly, 2011; Renfrew, 1977; Torrence et al., 2013).

The segment of the South American Andes range considered here, between $33^{\circ}$ $38^{\circ} \mathrm{S}$ (Fig. 1), presents a tectonic history conducive to the formation of obsidian deposits in arc and back-arc settings (Folguera et al., 2008; Kay et al., 2006; Stern, 2004). Coupled with intense glacial and fluvial geomorphic processes occurring during the late Quaternary, which have produced an intense secondary redistribution of obsidian nodules, the landscape of obsidian sources in northwestern Patagonia is complex, constituting both a challenge and an excellent opportunity to reconstruct patterns of human mobility and technological organization at different spatial scales.

In this paper, we present geochemical and technological results for archaeological obsidian assemblages from surface and stratigraphy contexts from northwestern Patagonia (Neuquén Province, Argentina), spanning the Holocene in a 
discontinuous fashion. These results are interpreted in reference to geological and geochemical information already available for obsidian sources (Durán et al., 2004; Giesso et al., 2011). The interdisciplinary results presented here constitute a step towards unraveling the structure of primary and secondary sources, their geochemical signatures and, on this basis, patterns of human provisioning, use, and discard of lithic artifacts in the heterogeneous landscape of northwestern Patagonia. We suggest that proportions of the different obsidian chemical types in archaeological assemblages provide a local proxy of histories of site use, specifically, intensity of human occupation (Smith, 2011). Building on this, and integrating data on the frequencies of projectile points, ceramics and rock art motifs, we present a preliminary reconstruction of the spatial organization of the mobile societies that inhabited northwestern Patagonia.

\section{Background: Andes range, study area and obsidian}

\subsection{Andes range: geology and ecology}

The Andes mountain range forms a 7,500 km long physiographic structure extending along the western margin of South America, from $10^{\circ} \mathrm{N}$ in Colombia to $53^{\circ} \mathrm{S}$ in Tierra del Fuego Island (Clapperton, 1993). Volcanic activity is discontinuous along this range, where discrete volcanic zones exhibit different characteristics (Stern, 2004). This research focuses on the southern volcanic zone, between $33^{\circ}-38^{\circ} \mathrm{S}$ (Fig. 1). The type of silicic volcanic activity that is conducive to the formation of obsidian deposits (Cabrera et al., 2011) is restricted to certain segments of the Andes. In this region, Andean obsidian deposits are associated with arc and back-arc settings, presenting varying ages of formation that extend from the late Pliocene to the Holocene (Folguera et al., 2008; Hildreth et al., 2009). Furthermore, these diverse geologic and chronological contexts, and the subsequent action of geomorphic processes produce different types of obsidian sources, from primary outcrops in the Andean highlands to secondary accumulations in ignimbrite deposits and fluvial landforms.

The Andes function as a topographic barrier to the prevailing westerly storm tracks, affecting the patterns of circulation and imposing a steep west-east gradient on precipitation effective moisture (Garreaud et al., 2009). Thus, annual precipitation varies from ca. $1100 \mathrm{~mm}$ close to the Chile-Argentina border, to $200-150 \mathrm{~mm}$ in the eastern lowlands of Argentina. Vegetation distribution follows the decreasing west-east precipitation gradient, where forest communities west of the Andes (Chile) and in 
confined Andean slopes of Argentina successively give way to the highland Altoandina phytogeographic province above 2,600 masl. Grass and shrub steppes develop as altitude and precipitation decrease towards the eastern Argentinean lowlands with characteristic desert vegetation of the Monte phytogeographic province (Chiapella and Ezcurra, 1999; León et al., 1998).

Northern Neuquén region (Fig. 1), where we focus our research, captures a large part of this landscape variation on a small spatial scale. The western part of the region exhibits relatively high precipitation ( $\geq 300 \mathrm{~mm} /$ year) producing patches of productive grasslands and restricted wetland, which are circumscribed due to the presence of a rugged terrain. This produces seasonally restricted access to highlands located above 1700 masl. The eastern part of the region, on the other hand, displays lower precipitation ( $\leq 150 \mathrm{~mm} /$ year) and a gentler relief, where the proportion of land available for human occupation during winter is comparably higher (Barberena, 2013).

2.2 Obsidian in the southern Andes of Argentina and Chile $\left(33^{\circ}-37^{\circ} \mathrm{S}\right)$

The first studies of obsidian at this latitudinal range started with a preliminary characterization of the Laguna del Maule source centered on the border between Argentina and Chile at $36^{\circ} \mathrm{S}$ (Seelenfreund et al., 1996). Afterwards, a macro regional obsidian survey was initiated in 2002 , leading to the discovery and preliminary characterization of five obsidian sources located between $33^{\circ}-37^{\circ} \mathrm{S}$, and extending from the eastern Argentinean lowlands to the Andean highlands (current Argentinean-Chilean border). In a joint and ongoing project with the University of Missouri Research Reactor (MURR), over 2000 source and artifact samples were analyzed with INAA and XRF (Cortegoso et al., 2012; Durán et al., 2004; Giesso et al., 2011). In addition, similar XRF analyses have been conducted for a smaller set of samples with different equipment at the Universitá della Calabria (Italy), seeking to compare methods and enhance source discrimination (De Francesco et al., 2006; Durán et al., 2012). Combined, these studies have produced a preliminary reconstruction of obsidian availability and use in the Andes of Central Argentina and Chile (Giesso et al., 2011). Currently, we aim at assessing the scale and dynamics of geomorphic redistribution of nodules from core areas (Shackley, 1992; Shelley, 1993), locating unknown sources identified only through artifacts, and introducing a firmer chronology to the artifact analysis by means of obsidian hydration dating (Garvey, 2012; Stevenson and Rogers, 
2016). Additionally, ongoing fieldwork continues to reveal new minor sources (Fernández et al., in prep.; Pérez et al., 2015).

Fig. 1. Study area and main obsidian sources between $33^{\circ}-38^{\circ} \mathrm{S}$.

From an archaeological perspective, this macro regional project involves research on both watersheds of the Andes and encompasses the full process of human exploration and colonization of the area, from 11,000 cal years BP to the timing of the Hispanic colonization of South America (Barberena, 2015; Cortegoso et al., 2016). A number of general distributional patterns were recorded at macro regional scales, which are currently the focus of more intensive research at smaller scale (Barberena et al., 2011; Salgán et al., 2015). The most intriguing of these patterns is the prevailing human use of the two main sources -Laguna del Maule and Las Cargas- that are located in the Andean highlands and, as interpreted so far, could only be accessed during the summer months. Therefore, the exploitation of these sources would have implied much higher energetic costs than the annually accessible sources located on the eastern lowlands Cerro Huenul and El Peceño- (Cortegoso et al., 2016). This is recorded in the wider archaeological distribution of obsidian from the highland sources in comparison with those from the lowlands, as well as in their earliest chronologies of human use (Cortegoso et al., 2012). In association with this pattern, obsidian transport records a dominant geographic vector of with a west-east axis. This is expressed in the dominant presence of obsidian from the highland Laguna del Maule source in the lowland deserts of La Payunia, in southern Mendoza Province, despite the closer presence of the Cerro Huenul source (Barberena et al., 2011; Salgán et al., 2012). This has been interpreted as a direct acquisition of obsidian at the Laguna del Maule highlands from the eastern lowlands, thereby providing a proxy for the spatial scale and structure of human home ranges during the late Holocene (Giesso et al., 2011; Salgán et al., 2012).

\section{Cerro Huenul source}

This is a secondary source with a wide and discontinuous spatial distribution (Barberena et al., 2011; Durán et al., 2004), presenting nodules contained within ignimbrite deposits associated with the Tilhué Formation, which has a Plio-Pleistocene chronology with ages ranging between 4 and 0.7 my (Folguera et al., 2008). This formation is composed of vulcanites and pyroclastites and covers an irregular area that 
includes highland and lowland settings ranging from 800 to 2000 masl (Groeber, 1946; Narciso et al., 2004; Zöllner and Amos, 1973). The erosion of the matrix of these pyroclastic deposits produces concentrations of nodules of varying lithology including obsidian usually clustered in gullies that erode the ignimbrites (Fig. 2). Maximum sizes recorded reach $10 \mathrm{~cm}$ along the major axis. We have recorded that not all the deposits of Tilhué Formation contain obsidian clasts of adequate size for knapping ( $\geq 4 \mathrm{~cm}$ ), as can be expected given the dynamics of formation and deposition of ignimbrites (Freundt et al., 2000). On the other hand, geomorphic processes transport and relocate obsidian nodules, disassociating them to some extent from their original geological context (Shackley, 1992).

Fig. 2. Secondary deposits of the Cerro Huenul obsidian source.

\section{Laguna del Maule source}

The core of this source is located in the VII region of Chile, in the Maule volcanic area, at ca. 2300 masl (Seelenfreund et al., 1996). Obsidian outcrops are situated at the Maule river headwaters, clustering close to the homonymous lake in the Andean highlands. The Quaternary geologic formation containing obsidian is the “Complejo volcánico Laguna del Maule" (Hildreth et al., 2009) that covers ca. $500 \mathrm{~km}^{2}$ on both sides of the Argentina-Chile border (Fierstein et al., 2014). Within the Maule area, eight spatially restricted subsources were originally identified that exhibit nodules with macroscopic distinctive attributes (color, size, flaking quality). According to PIXEPIGME geochemical analyses, these sources can be grouped in two types: Maule 1and Maule 2 (Seelenfreund et al., 1996). Samples from each outcrop record the macroscopic variability of Maule obsidian. Its color ranges from translucent gray to homogeneous black, including gray, banded black, brown, and pale red. Its flaking quality ranges from excellent to poor, depending on the presence of phenocrysts or cracks produced by weathering. Obsidian available at the core-area varies from angular pebbles to large blocks up to $8 \mathrm{~m}^{3}$ (Fig. 3). Evidence of human exploitation of the full range of macroscopic varieties is available at the source, even for specimens of very low flaking quality (Seelenfreund et al., 1996).

Quantitative geoarchaeological information to gauge secondary redistribution of Maule obsidian nodules in the region, especially downstream along the Barrancas river basin discharging the Fea and Negra lagoons, is still missing. However, the recent 
geochemical analysis that we performed on a nodule from the Neuquén river basin allows assigning it to Laguna del Maule 2, proving the occurrence of such geomorphic processes. Therefore, the spatial scale of Maule source requires a more accurate definition yet. Below we present a preliminary geoarchaeological assessment of the secondary redistribution of nodules from this source along the Barrancas river basin.

Fig. 3. Primary outcrops and large obsidian blocks of Laguna del Maule type in Lagunas Fea and Negra locality (Neuquén Province, Argentina).

\section{Materials and Methods}

\subsection{Materials}

We present new results for a total of 266 lithic artifacts from diverse surface $(N=$ 156) and stratigraphic $(\mathrm{N}=110)$ assemblages within the Barrancas - Buta Ranquil region (Neuquén Province, Argentina; Fig. 4). Considering the previous chemical characterization of 38 artifacts (Barberena et al., 2011), the total sample sums to 304 artifacts characterized by means of XRF. The selection of artifacts from each site was directed towards two goals. On the one hand, it sought to include specimens from successive stages along the reduction sequence. On the other hand, it focused on targeting those artifact types that may have been part of transported toolkits (e.g., projectile points, bifacial thinning flakes), since this would increase the chances of intercepting non-local obsidian types (Eerkens et al., 2002; Kuhn, 2004). This sampling strategy was selected to explore geochemical diversity in different artifact classes. Admittedly, the composition of the sample analyzed may not be representative of the technological variation within each assemblage. This will be the goal in our next research step that will be based on a random sampling of the assemblages across the region.

Fig. 4. Location of obsidian sources, geoarchaeological, and archaeological samples.

References:

Geoarchaeological samples from the Barrancas River: 1. Lagunas Negra-Fea primary outcrops (Laguna del Maule obsidian); 2. Pampa del Rayo secondary deposits (Laguna del Maule obsidian); 3. Geoarchaeological sampling units 1, 2, and 3; 4. 
Geoarchaeological sampling units 4 and 5; 5. Geoarchaeological sampling units 8 through 13.

Archaeological samples, this paper: 6. Cueva Huenul; 7. Cueva Yagui; 8. Puesto Cuello; 9. Buta Có Arriba; 10. Paso de las Tropas; 11. Laguna Chica del Tromen; 12. El Ciénego

Archaeological samples, Barberena et al. 2011: 13. El Comienzo rockshelter; 14. Cueva Pava.

The sample from stratigraphic contexts comes from two sites with associated temporal information bracketing the artifacts: Cueva Huenul $1(\mathrm{~N}=120)$ and Cueva Huenul $3(\mathrm{~N}=10)$. Cueva Huenul 1 is a large cave with a sequence composed of two main archaeological components dated between 11,000-10,200 cal years BP (component 2, $\mathrm{N}=36$ ) and 1800-300 cal years BP (component $4, \mathrm{~N}=84$ ), respectively (dates and contextual data in Barberena, 2015; Barberena et al., 2015). The 15 dates available for this site indicate temporal integrity of the assemblages, lending support to the temporal assignment of the artifacts. The archaeological site Cueva Huenul 3, on the other hand, is a small rock-shelter that presents a basal date of $\leq 1500$ cal years BP on charcoal from an anthropogenic feature $\left({ }^{14} \mathrm{C}\right.$ age $=1562 \pm 40$ [AA-102576] $)$, which can be used as a terminus post quem age for the lithic assemblages.

In the discussion we integrate other lines of evidence from two shelter sites that provide a majority of the artifacts characterized: Cueva Huenul 1 and Cueva Yagui (Fig. 5). Both sites contain stratified deposits; those from $\mathrm{CH} 1$ are described above, but those from Cueva Yagui have not yet been geochemically characterized.

Fig.5. Archaeological sites with obsidian samples from stratigraphic contexts: (a) Cueva Huenul 1; (b) Cueva Yagui.

3.2 Methods and previous results on the sources

Trace element analyses on sources were performed by instrumental neutron activation (INAA) and X-ray fluorescence (XRF) in the MURR Archaeometry Laboratory, and have already been published (Barberena et al., 2011; Cortegoso et al., 2012; Giesso et al., 2011). INAA has more sensitivity and precision for most elements (except $\mathrm{Sr}$ and $\mathrm{Zr}$ ), and can analyze smaller samples than XRF with greater accuracy, but at the same time it is destructive and more time-consuming (Glascock et al., 2007; 
Shackley, 2011). These systematic results on the sources provide the current frame of reference for the chemical assignment of artifacts. In Tables 1 and 2 we present a synthesis of the INAA and XRF results for the main sources present in the region. In Fig. 6 we present a scatterplot built from INAA data showing results for cerium and rubidium, which are the elements best discriminating these sources (data from Giesso et al., 2011).

Fig. 6. Plot of $\mathrm{Ce}$ and $\mathrm{Rb}$ values from INAA (ellipses are drawn at the $90 \%$ confidence level).

Table 1. Geochemical composition of the sources Cerro Huenul and Laguna del Maule1 and 2 by means of INAA.

\begin{tabular}{|c|c|c|c|c|c|c|}
\hline \multirow{4}{*}{$\begin{array}{c}\text { Element } \\
\text { (ppm) } \\
\mathrm{Ba}\end{array}$} & \multicolumn{2}{|c|}{ Cerro Huenul } & \multicolumn{2}{|c|}{ Laguna del Maule 1} & \multicolumn{2}{|c|}{ Laguna del Maule 2} \\
\hline & \multicolumn{2}{|c|}{$(\mathrm{N}=16)$} & \multicolumn{2}{|c|}{$(\mathrm{N}=45)$} & \multicolumn{2}{|c|}{$(\mathrm{N}=4)$} \\
\hline & Average & $\begin{array}{l}\text { Standard } \\
\text { deviation }\end{array}$ & Average & $\begin{array}{l}\text { Standard } \\
\text { deviation }\end{array}$ & Average & $\begin{array}{l}\text { Standard } \\
\text { deviation }\end{array}$ \\
\hline & 682 & 18 & 703 & 17 & 652 & 11 \\
\hline $\mathrm{La}$ & 16.9 & 0.4 & 33.3 & 0.7 & 31.7 & 0.2 \\
\hline $\mathrm{Lu}$ & 0.25 & 0.03 & 0.36 & 0.03 & 0.43 & 0.04 \\
\hline $\mathrm{Nd}$ & 10.7 & 1.3 & 23.6 & 1.7 & 20.4 & 1.3 \\
\hline $\mathrm{Sm}$ & 2.34 & 0.10 & 4.50 & 0.12 & 3.86 & 0.04 \\
\hline $\mathrm{U}$ & 4.15 & 0.28 & 5.35 & 0.48 & 6.09 & 0.15 \\
\hline $\mathrm{Yb}$ & 1.39 & 0.05 & 2.03 & 0.04 & 1.83 & 0.10 \\
\hline $\mathrm{Ce}$ & 32.8 & 0.9 & 65.5 & 2.1 & 60.2 & 0.3 \\
\hline Co & 0.24 & 0.01 & 0.22 & 0.13 & 0.20 & 0.04 \\
\hline Cs & 4.24 & 0.08 & 4.55 & 0.11 & 5.72 & 0.04 \\
\hline $\mathrm{Eu}$ & 0.39 & 0.01 & 0.74 & 0.03 & 0.54 & 0.01 \\
\hline $\mathrm{Fe}$ & 5114 & 117 & 7488 & 472 & 6036 & 167 \\
\hline $\mathrm{Hf}$ & 2.44 & 0.06 & 5.16 & 0.29 & 4.16 & 0.05 \\
\hline $\mathrm{Rb}$ & 104 & 2 & 157 & 3 & 178 & 1 \\
\hline $\mathrm{Sb}$ & 0.15 & 0.01 & 0.29 & 0.02 & 0.34 & 0.01 \\
\hline Sc & 1.61 & 0.03 & 2.32 & 0.07 & 2.37 & 0.02 \\
\hline $\mathrm{Sr}$ & 131 & 19 & 116 & 33 & 114 & 98 \\
\hline $\mathrm{Ta}$ & 1.22 & 0.03 & 0.98 & 0.12 & 1.04 & 0.01 \\
\hline $\mathrm{Tb}$ & 0.32 & 0.02 & 0.51 & 0.02 & 0.43 & 0.02 \\
\hline Th & 9.18 & 0.19 & 19.9 & 0.5 & 22.9 & 0.2 \\
\hline $\mathrm{Zn}$ & 27.7 & 2.2 & 47.0 & 6.0 & 33.6 & 0.5 \\
\hline $\mathrm{Zr}$ & 95 & 8 & 202 & 17 & 169 & 7 \\
\hline $\mathrm{Al}(\%)$ & 7.08 & 0.32 & 7.53 & 0.28 & 6.78 & 0.70 \\
\hline $\mathrm{Cl}$ & 356 & 64 & 775 & 159 & 689 & 52 \\
\hline Dy & 1.63 & 0.22 & 2.78 & 0.37 & 2.62 & 0.29 \\
\hline $\mathrm{K}(\%)$ & 3.23 & 0.20 & 3.46 & 0.14 & 3.87 & 0.18 \\
\hline
\end{tabular}




\begin{tabular}{c|cccccc|}
$\mathrm{Mn}$ & 675 & 15 & 590 & 13 & 500 & 6 \\
$\mathrm{Na}(\%)$ & 3.20 & 0.06 & 3.58 & 0.05 & 3.18 & 0.03 \\
\cline { 2 - 5 } & & &
\end{tabular}

Table 2. Geochemical composition of the sources Cerro Huenul and Laguna del Maule 1 and 2 by means of XRF.

\begin{tabular}{|c|c|c|c|c|c|c|}
\hline \multirow{3}{*}{$\begin{array}{c}\text { Element } \\
\text { (ppm) }\end{array}$} & \multicolumn{2}{|c|}{ Cerro Huenul } & \multicolumn{2}{|c|}{ Laguna del Maule 1} & \multicolumn{2}{|c|}{ Laguna del Maule 2} \\
\hline & \multicolumn{2}{|c|}{$(\mathrm{N}=12)$} & \multicolumn{2}{|c|}{$(\mathrm{N}=16)$} & \multicolumn{2}{|c|}{$(\mathrm{N}=7)$} \\
\hline & Average & $\begin{array}{l}\text { Standard } \\
\text { deviation }\end{array}$ & Average & $\begin{array}{l}\text { Standard } \\
\text { deviation }\end{array}$ & Average & $\begin{array}{l}\text { Standard } \\
\text { deviation }\end{array}$ \\
\hline $\mathrm{Ti}$ & 818 & 77 & 956 & 103 & 912 & 109 \\
\hline $\mathrm{Mn}$ & 492 & 39 & 466 & 63 & 390 & 56 \\
\hline $\mathrm{Fe}$ & 4881 & 310 & 6907 & 665 & 5703 & 385 \\
\hline $\mathrm{Zn}$ & 22 & 2 & 31 & 4 & 28 & 3 \\
\hline $\mathrm{Ga}$ & 14 & 1 & 15 & 1 & 15 & 1 \\
\hline $\mathrm{Rb}$ & 95 & 4 & 148 & 8 & 165 & 4 \\
\hline $\mathrm{Sr}$ & 110 & 7 & 94 & 19 & 75 & 12 \\
\hline $\mathrm{Y}$ & 14 & 1 & 19 & 2 & 17 & 3 \\
\hline $\mathrm{Zr}$ & 71 & 4 & 164 & 21 & 126 & 7 \\
\hline $\mathrm{Nb}$ & 12 & 1 & 12 & 2 & 12 & 2 \\
\hline
\end{tabular}

Trace element analyses on the artifacts were performed in March 2014 using a portable spectrometer Bruker Tracer III-V from the MURR Archaeometry Laboratory at the Laboratorio de Paleoecología Humana, Facultad de Ciencias Exactas y Naturales, Universidad Nacional de Cuyo (Mendoza, Argentina). This type of XRF analysis is non-destructive and allows simultaneous measurement of 13 chemical elements: potassium $(\mathrm{K})$, titanium $(\mathrm{Ti})$, manganese $(\mathrm{Mn})$, iron $(\mathrm{Fe})$, zinc $(\mathrm{Zn})$, gallium $(\mathrm{Ga})$, rubidium $(\mathrm{Rb})$, strontium $(\mathrm{Sr})$, yttrium $(\mathrm{Y})$, zirconium $(\mathrm{Zr})$, niobium $(\mathrm{Nb})$, lead $(\mathrm{Pb})$, and thorium (Th). The instrument generates a spectral representation of the chemical elements present in each source and artifact specimen. After peak fitting, the concentration data for artifacts and sources can be compared to determine the source for each artifact. Diagnostic elements for discriminating obsidian sources in this region are rubidium, strontium, and zirconium. Portable spectrometers are being increasingly used worldwide for fast, accurate, and non-destructive determinations of the chemical signatures of artifacts (Millhauser et al., 2011; Pintar et al., 2016). The instrument was calibrated using a suite of 40 obsidian sources analyzed by multiple methods at MURR as described in Glascock and Ferguson (2012). 
The main purpose of the technological analysis presented here is to compare the composition, or the technological lithic structure, of the two main subsamples discriminated by geochemical means: the artifacts assigned to the local Cerro Huenul chemical type vs. those assigned to Laguna del Maule 1 and 2 types. We utilize standard techno-morphological properties to group the artifacts in classes: external flakes, internal flakes, resharpening flakes, cores, and tools (Andrefsky, 2001). We characterize technological variables with the goal of placing the artifacts along a continuum of reduction (Kuhn, 2004; Shott, 2003). We also recorded a number of characteristics of the raw material (color, knapping quality, textures, presence of phenocrysts, and surface alteration) to explore whether the geochemical difference among sources is correlated with macroscopic attributes.

Previous research indicates that Laguna del Maule sources provide the largest part of the obsidian represented in archaeological assemblages from the neighboring southern Mendoza area (e.g., La Payunia volcanic field, Grande River), in spite of the supposed closer location to the alternative Cerro Huenul source. As mentioned above, this pattern was interpreted as seasonal access to the Andean highlands from the eastern lowlands, implying large west-east circuits of human mobility (Cortegoso et al., 2012; Giesso et al., 2011; Salgán et al., 2014). Nevertheless, the impact of geomorphic redistribution processes of obsidian nodules from the Laguna del Maule highlands towards the lowlands has not yet been examined systematically. The Barrancas River, draining the highlands, may have had a key role in the redistribution of this obsidian. We conducted field sampling of the fluvial deposits at different altitudes and present preliminary results in the following section.

\section{Results}

\subsection{Geoarchaeological observations on Laguna del Maule source}

We surveyed the Barrancas River from its upper basin (ca. 2300 masl), where the primary obsidian outcrops are located, up to its lower basin where it converges with the Grande River forming the Colorado River (ca. 1000 masl, Fig. 4). In the upper section we sampled primary lava flows composed of obsidian located between Laguna Fea and Laguna Negra, where large angular boulders of up to $2 \mathrm{~m}$ eroded from the outcrops (Fig. 3). These outcrops make up the eastern part of the Laguna del Maule complex (Seelenfreund et al., 1996). In the area known as Pampa del Rayo, located 
between 3-6 km downriver (Fig. 4), we recovered a large number of angular blocks reaching $40 \mathrm{~cm}$ along the major axis.

In the following localities, which are further from the primary outcrops, we conducted a different sampling strategy adequate to assess the presence of obsidian nodules contained in the fluvial deposits. In each location, three people conducted 150 m-long transects following the main axis of the river, recording and collecting obsidian nodules. Each sampling unit covered approximately $1500 \mathrm{~m}^{2}$ of surface and was separated from the next by $200 \mathrm{~m}$ that were not sampled thoroughly, though they were also inspected. Sampling units 1, 2, and 3 are located $55 \mathrm{~km}$ downriver (1217-1202 masl). We did not recover obsidian nodules. Sampling units 4 and 5 are located $72 \mathrm{~km}$ downriver, in the mouth of the Huaracó creek (Fig. 4). In unit 4 we recovered a large number of rounded and sub rounded obsidian nodules ranging between 43 and $80 \mathrm{~mm}$ along the major axis, while in unit 5 we recovered only one nodule. Outside of the sampling units we recovered a maximum nodule' size of $95 \mathrm{~mm}$. The sampling units 8 through 13 are located between 80-90 km downriver from the primary outcrops. In the units 8 and 9 we recovered obsidian nodules reaching up to $50 \mathrm{~mm}$ along the major axis. Intriguingly, these nodules were angular and were associated to a localized ignimbrite deposit. Finally, in the sampling units 10, 11, 12, and 13 we did not recover obsidian nodules.

The preliminary analysis conducted here extends the area of availability of Laguna del Maule obsidian up to ca. $90 \mathrm{~km}$ from the primary outcrops already known (Seelenfreund et al., 1996). As could be expected, the Barrancas River transports obsidian nodules towards the lowlands, allowing yearly access to this raw material. The field sampling indicates a downriver size-decreasing trend of obsidian nodules. Importantly, the sampling units 1,2 , and 3 , located only $55 \mathrm{~km}$ from the primary source, did not contain obsidian, while other sampling units located at further distances did. While preliminary, this finding suggests that obsidian distribution along the Barrancas River is heterogeneous. Under further field and morphometric analyses, we will assess the geomorphic processes that control this distribution, while geochemical results will allow determining the chemical types of the obsidian recovered in the fluvial deposits (Fernández et al., in prep.).

4.2 Geochemical determination of provenance 
There is an important difference in key chemical elements between Cerro Huenul and Laguna del Maule 1 and 2 chemical types. Cerro Huenul has significantly lower $\mathrm{Rb}, \mathrm{Zr}, \mathrm{Zn}$, and Fe, and higher Mn than Laguna del Maule 1 and 2, as recorded for both NAA and XRF (Tables 1 and 2). Considering NAA, Cerro Huenul has a significantly lower abundance of Ce and Hf than Laguna del Maule 1 and 2. The differences between Laguna del Maule 1 and 2 subtypes are considerably smaller regarding these elements. Field and lab analyses of source samples currently underway will provide a stronger basis to assess the spatial patterns in the distribution of Laguna del Maule 1 and 2 types, as well as the existence of macroscopic differences. At a regional scale, the two Laguna del Maule chemical types are available at the same area (Seelenfreund et al., 1996). Considering that the Laguna del Maule 1 type is present in low frequency in our archaeological sample, we aggregate these two types for discussion.

Table 1 of the Supplemental Material shows the full geochemical results for artifacts. In Fig. 7, we present the scatterplots of two pairs of elements ( $\mathrm{Rb}-\mathrm{Zr}$ and $\mathrm{Nb}-$ $\mathrm{Zr}$ ) measured for the 266 artifacts in this study. These plots provide an example illustrating the striking differences between the sources recorded in the region at an archaeological level. As has been pointed out before (Giesso et al., 2011), Cerro Huenul source is characterized by low geochemical variability, despite the existence of remarkable macroscopic variation. Of the analyzed artifacts, $89 \%(\mathrm{~N}=237)$ is assigned to the Cerro Huenul source, while $11 \%$ to Laguna del Maule $1(\mathrm{~N}=6)$ and Laguna del Maule $2(\mathrm{~N}=23)$ chemical types.

Fig. 7. Plots of the (a) $\mathrm{Rb}-\mathrm{Zr}$ and (b) $\mathrm{Nb}-\mathrm{Zr}$ values for archaeological assemblages from northern Neuquén $(\mathrm{N}=266)$.

There is no record of other important sources available at a macro-regional scale, such as the significant source at Portada Convunco, located ca. $180 \mathrm{~km}$ to the south (Stern et al., 2012), or the sources known for Mendoza Province located between ca. 160-300 km (Las Cargas and Laguna del Diamante, in the highlands, and El Peceño, in the lowlands; Durán et al., 2004; Cortegoso et al., 2012). In addition, none of the samples were assigned to undetermined geochemical types (following those reported by Giesso et al., 2011). This restricted transport is an interesting finding that may fit into a larger scale pattern of obsidian consumption behaviors. 


\subsection{Temporal patterns: Cueva Huenul locality}

The archaeological sites $\mathrm{CH} 1$ and $\mathrm{CH} 3$ (Fig. 5) provide a stratigraphic sample composed of 130 artifacts with associated temporal information. As already mentioned, we produced a robust chrono-stratigraphic sequence for $\mathrm{CH} 1$ based on 15 radiocarbon dates that allows defining two temporal components respectively dated between 11,000 10,200 cal BP (component 2, N=36) and 1800-300 cal BP (component 4, N=84) (Barberena, 2015). CH3, on the other hand, presents a basal date of $\leq 1500$ cal BP that provides a maximum age for 10 artifacts that were characterized by XRF. These two sites are located within the range of availability of Cerro Huenul obsidian. As would be expected, this local obsidian type dominates the stratigraphic assemblages $(\mathrm{N}=123$, $94.6 \%$ ). Only seven artifacts were assigned to Laguna del Maule 1 and 2 types: six of them come from late Holocene layers, while one of the artifacts assigned to Laguna del Maule 2 comes from the levels bracketed between 11,000-10,200 cal years BP. This case complements other previously known determinations, such as those from Gruta El Manzano, Arroyo Malo 3, and Gruta El Mallín sites that record the utilization of obsidian from Laguna del Maule since the early Holocene (Cortegoso et al., 2012; Giesso et al., 2011; Neme et al., 2011).

\subsection{Lithic technology}

The set of artifacts assigned to Cerro Huenul include all the stages of the reduction sequence (Table 3$)$ : cores $(6.3 \%)$, external or cortical flakes $(15.2 \%)$, internal flakes (35.9\%), unifacial (2.5\%) and bifacial tools (23.3\%), and resharpening flakes $(2.9 \%)$. The artifacts assigned to Laguna del Maule, on the other hand, do not include the classes corresponding to early stages of the reduction sequence (external flakes and cores). The category most represented is internal flakes (41.4\%), followed by bifacial $(34.4 \%)$ and unifacial tools (3.5\%). While the large boulders of the primary Laguna del Maule source in the highlands do not present significant development of cortex, the secondary nodules that we have recorded in the survey of the Barrancas River, which is closer to the study area, do. This is relevant for the analysis of lithic reduction and will be a focus of future geoarchaeological work.

Table 3. Technological composition of the obsidian assemblages by chemical type. 


\begin{tabular}{|c|c|c|c|c|c|c|c|c|c|c|c|c|c|c|c|c|c|}
\hline \multirow[t]{2}{*}{$\begin{array}{l}\text { Obsidian } \\
\text { type }\end{array}$} & \multicolumn{2}{|c|}{$\begin{array}{l}\text { External } \\
\text { flakes }\end{array}$} & \multicolumn{2}{|c|}{$\begin{array}{l}\text { Internal } \\
\text { flakes }\end{array}$} & \multicolumn{2}{|c|}{ Cores } & \multicolumn{2}{|c|}{$\begin{array}{c}\text { Core } \\
\text { reactivation } \\
\text { flakes }\end{array}$} & \multicolumn{2}{|c|}{$\begin{array}{l}\text { Unifacial } \\
\text { tools }\end{array}$} & \multicolumn{2}{|c|}{$\begin{array}{l}\text { Bifacial } \\
\text { tools }\end{array}$} & \multicolumn{2}{|c|}{$\begin{array}{c}\text { Resharpening } \\
\text { flakes }\end{array}$} & \multicolumn{2}{|c|}{$\begin{array}{c}\text { Undetermined } \\
\text { artifacts }\end{array}$} & \multirow[t]{2}{*}{ Total } \\
\hline & $\mathbf{N}$ & $\%$ & $\mathbf{N}$ & $\%$ & $\mathbf{N}$ & $\%$ & $\mathbf{N}$ & $\%$ & $\mathbf{N}$ & $\%$ & $\mathbf{N}$ & $\%$ & $\mathbf{N}$ & $\%$ & $\mathbf{N}$ & $\%$ & \\
\hline C. Huenul & 36 & 15.2 & 85 & 35.9 & 15 & 6.3 & 2 & 0.8 & 6 & 2.5 & 55 & 23.3 & 5 & 2.1 & 33 & 13.9 & 237 \\
\hline L. Maule & 0 & 0 & 12 & 41.4 & 0 & 0 & 1 & 3.5 & 1 & 3.5 & 10 & 34.4 & 0 & 0 & 5 & 17.2 & 29 \\
\hline Total & 36 & 13.5 & 97 & 36.5 & 15 & 5.6 & 3 & 1.1 & 7 & 2.6 & 65 & 24.5 & 5 & 1.9 & 38 & 14.3 & 266 \\
\hline
\end{tabular}

The absence of the early stages of reduction of Laguna del Maule types is consistent with the availability of nodules in secondary contexts of the Barrancas and Colorado Rivers located between 10-20 km from the archaeological contexts studied here. On the other hand, the artifacts assigned to Cerro Huenul obsidian, a raw material immediately available ( $<5 \mathrm{~km}$, sensu Civalero and Franco, 2003) in most of the region, are represented by the full reduction sequence, including cores, external flakes, and tools.

\section{Discussion}

5.1 Geoarchaeology and spatial structure of the sources: Laguna del Maule

Our preliminary geoarchaeological survey in the fluvial deposits of the

Barrancas River provide evidence of the availability of obsidian in secondary contexts at least $90 \mathrm{~km}$ downriver from the Laguna del Maule primary outcrops, reaching at least 1000 masl. Geochemical analyses of these samples currently underway will allow testing the chemical composition of these nodules (Fernández et al., in prep.), though the geomorphic context and macroscopic features suggest that they would be derived from the outcrops of Laguna del Maule (Seelenfreund et al., 1996). This finding implies reassessing previous interpretations of seasonal mobility linking the eastern plains and the highlands recurrently, in the context of large east-west annual circuits (Giesso et al., 2011; Salgán et al., 2014). This would also require reformulating hypotheses aiming at explaining the under-representation of Cerro Huenul obsidian compared to Laguna del Maule in the adjacent La Payunia volcanic field of southern Mendoza Province (Barberena et al., 2011).

Considering that Laguna del Maule obsidian would also be available in the lowlands, in contexts that are accessible year-round, we can suggest that: a) it does not necessarily imply access to the Andean highlands; and b) it would be located even closer than Cerro Huenul obsidian to the areas adjacent to the fluvial system of the Barrancas-Colorado rivers. This applies in particular to southeastern Mendoza, where a 
decreasing frequency of artifacts knapped on Laguna del Maule obsidian is recorded with increasing distance from this basin (Salgán et al., 2012, 2014).

\subsection{Understanding regional modes of obsidian use}

On the basis of the geoarchaeological, geochemical, and technological results presented here, we develop a first assessment of the modes of transport and discard of the different obsidian types. Our geochemical results indicate that Cerro Huenul obsidian predominates in all of the surface and stratigraphy assemblages. This is consistent with the immediate availability ( $<5 \mathrm{~km}$ from the sites) of this raw material in different ignimbrite deposits of the region. On the other hand, the geoarchaeological results suggest that Laguna del Maule obsidian is available in secondary fluvial deposits located between 10-20 km from the archaeological contexts sampled. While both obsidian types would be included within typical foraging range (Kelly, 1995; Marlowe, 2005), the provisioning of Laguna del Maule obsidian requires longer trips, explaining its lower frequency. In Ericson's terms, Cerro Huenul obsidian shows terminal reduction, where the full sequence is locally represented, while Laguna del Maule obsidian is represented only by final/advanced stages of the reduction sequence, being compatible with a sequential reduction pattern (Ericson, 1984). On this basis, we suggest that the structure of the obsidian sources on a micro-regional scale plays a key role in the modes of transport and discard.

In addition, and considering that both obsidian types are available within $20 \mathrm{~km}$ from the archaeological sites, we suggest that the 'place use histories' (Holdaway and Wandsnider, 2006) of each site are another factor that may have contributed to the rates of discard of the different obsidian types. When compared to sites with brief and intermittent occupations, we expect that those contexts with a more intensive and/or recurrent occupation history will present: a) higher diversity of lithic raw materials and, accordingly, a higher proportion of the less ubiquitous Laguna del Maule obsidian; and b) higher rates of tool discard (Andrefsky, 2001; Bettinger et al., 1994; Holdaway and Wandsnider, 2006; Veth, 2005). The database currently available only allows for an initial exploration of this source of variation. If developed in combination with geoarchaeological information on the spatial structure of the sources, this comparison contributes to our understanding of different place use histories within the region, and their role in the composition of obsidian assemblages. 
We present a preliminary comparison of the two shelter sites providing the bulk of the obsidian artifacts characterized for the region (see Fig. 5): Cueva Huenul 1 (N= $123)$ and Cueva Yagui $(\mathrm{N}=60)$ account for $60.2 \%$ of the region's known sample $(\mathrm{N}=$ 304, including the results published in Barberena et al., 2011). We compare the proportion of the obsidian types with preliminary information on different proxies of site occupation: density of lithic projectile points in stratigraphy, of ceramic sherds in stratified and surface contexts, and frequency of rock art motifs (Table 4, see details in Romero and Re, 2014; Rughini, 2016).

Table 4. Occupational proxies for Cueva Huenul 1 and Cueva Yagui sites.

\begin{tabular}{|l|c|c|}
\hline \multicolumn{1}{|c|}{ Occupational proxy } & Cueva Huenul 1 & Cueva Yagui \\
\hline Sediment volume $\left(\mathrm{m}^{3}\right)$ & 3.8 & 1.4 \\
\hline \% of Cerro Huenul obsidian & 94.3 & 80 \\
$(\mathrm{~N}=116)$ & $(\mathrm{N}=48)$ \\
\hline $\begin{array}{l}\text { \% of Laguna del Maule } \\
\text { obsidian }\end{array}$ & 5.7 & 20 \\
$(\mathrm{~N}=7)$ & $(\mathrm{N}=12)$ \\
\hline Density of projectile points/ & 1.9 & 22.7 \\
sediment volume & $(\mathrm{N}=8)$ & $(\mathrm{N}=34)$ \\
\hline N of ceramic sherds $(*)$ & 5 & 64 \\
\hline N of rock art motifs & 240 & 178 \\
\hline
\end{tabular}

References: $\left(^{*}\right)$ includes samples from stratigraphy and shelter surface.

The combined analysis of the different occupational proxies indicates that these sites have different histories of place use. On the basis of the low proportion (5.7\%) of Laguna del Maule obsidian, low density of lithic projectile points, and low frequency of ceramic sherds (Table 4), the human occupations of Cueva Huenul 1 can be characterized as transient. The existence of large temporal gaps of human presence supports this interpretation (Barberena, 2015). Cueva Yagui, on the other hand, has a higher proportion of Laguna del Maule obsidian (20\%), a higher density of projectile points, and a significantly higher frequency of ceramic sherds (Table 4). These proxies combined indicate an intense occupational history and a higher diversity of activities for Cueva Yagui when compared to Cueva Huenul 1. This may be the behavioral context for the higher discard of Laguna del Maule obsidian in Cueva Yagui. Interestingly, both 
sites have large frequencies of rock art motifs with Cueva Huenul showing the highest value $(\mathrm{N}=240)$ for the region (Romero and $\mathrm{Re}, 2014)$.

In synthesis, our results provide a basis to assess different place use histories for these two shelter sites with long temporal sequences (Cueva Yagui has a basal date of ca. 8000 cal years BP, Romero Villanueva et al., 2017). We suggest that these occupational histories provide the context to interpret the frequency of Laguna del Maule obsidian in the region when compared to the immediately available Cerro Huenul obsidian. The production of rock art in Cueva Huenul 1, which attests to an active human role at the site, appears to occur with some degree of independence from the other proxies of human use, which suggest ephemeral occupation even during the late Holocene. This opens up fascinating research question regarding diverse behavioral dimensions that condition the human occupation of different sites and areas within the region.

\subsection{Conclusions and future perspectives}

At a geoarchaeological level, we have conducted a survey in the Barrancas River basin, allowing a first reassessment of the spatial structure of the source. On this basis, we suggest that this obsidian is not only available as primary outcrops in the highlands (2300-2500 masl), but also reaches low-altitude areas in the form of nodules transported by fluvial action up to at least $90 \mathrm{~km}$ from the primary outcrops (ca. 1000 masl). This finding will lead to reassess previous interpretations on the scale and geographic vectors of human mobility. The next step will be to produce morphometric and geochemical studies of the secondary obsidian deposits in this fluvial basin, as well as in the Neuquén River.

At an archaeological level, we have presented a large geochemical and technological database for artifacts from the Barrancas-Buta Ranquil locality in northern Neuquén. These results allow describing different trajectories for the obsidian assigned to Cerro Huenul type, which is immediately available $(<5 \mathrm{~km})$ in relation to the archaeological assemblages, and the obsidian from the two Laguna del Maule types, which is available within $20 \mathrm{~km}$ from these sites. Cerro Huenul obsidian dominates in all of the assemblages and is represented by the full reduction sequence. Laguna del Maule obsidian, in contrast, is recorded in lower frequencies and is only represented by advanced stages of the reduction process. In this context, we suggest that the rate and mode of discard of Laguna del Maule obsidian can be used as a proxy of the history of 
place use of different sites within the region, in addition to the rates of discard of projectile points, ceramic sherds, and the frequency of rock art motifs. We developed a first exploratory comparison utilizing the cave sites Cueva Huenul 1 and Cueva Yagui, which not only are the most intensively studied for the region, but also are respectively located on different landscape areas. CuevaYagui is only $50 \mathrm{~m}$ from the permanent Buta Có Creek (1300 masl), in a transitional area between the dry Monte and the colder and more humid Patagonia phytogeographical Province. Cueva Huenul 1, on the other hand, is emplaced in the dry Monte area (1000 masl), $4 \mathrm{~km}$ from the Colorado River, which is the nearest predictable water source. The frequency of obsidian from Laguna del Maule is considerably higher in Cueva Yagui than in Cueva Huenul 1. While the immediate association of Cueva Huenul 1 with Cerro Huenul obsidian source contributes to this pattern, we suggest that the occupational history of the sites contributes to explain this pattern. Cueva Yagui presents a considerably higher density of tools that formed part of transported kits and a much higher density of ceramics, which we suggest could be used as a proxy of occupational intensity in this region.

This paper allows us to define the next steps in our interdisciplinary research with obsidian. On the one hand, we have to define the spatial structure of the Laguna del Maule source in much finer detail, a task that will imply systematic survey of different fluvial basins within northern Neuquén. On the other hand, we have to assess the geochemical variation in the different primary and secondary manifestations of this source and its relation with macroscopic characteristics. In addition, Cueva Yagui site with its 8000-years-long-sequence will provide a chance to conduct a first approach to obsidian hydration studies (Stevenson and Rogers, 2016). We will also apply this method to surface assemblages with the goal of providing qualitative information on the tempo of formation. Considering that this sequence has a large number of projectile points with different properties, we will articulate this with an analysis of technological change through time. The geochemical and technological analysis of obsidian assemblages from this region provides a key frame for the analysis of reduction sequences and place use histories. We look forward for the systematic integration of the obsidian research with wider distributional databases for rock art and ceramic records.

\section{Acknowledgments}

CONICET (PIP 2015-2017) and Agencia Nacional de Promoción de la Ciencia y la Tecnología (PICT 2014-0940) from Argentina funded this research. This work was 
also supported by a grant to the MURR Archaeometry Lab from the US National Science Foundation (1415403). Juan Pablo Aguilar and Claire Holubowskyj helped during geoarchaeological fieldwork. We acknowledge Claudia Della Negra, Pablo Azar, Estela Cúneo, and Liliana Martínez (Subsecretaría de Cultura de la Provincia del Neuquén) for their continuous help. This research is possible due to the support from Juvenal Urrutia, Paulina Valenzuela, Javier Siegel, Hugo Zalazar, and the communities from Barrancas and Buta Ranquil (Neuquén Province, Argentina).

\section{References}

Andrefsky, W., 2001. Lithic debitage: context, form, meaning. University of Utah Press, Salt Lake City.

Barberena, R., 2013. Biogeografía, competencia y demarcación simbólica del espacio: modelo arqueológico para el norte de Neuquén. Intersecciones Antropol. 14, 367-382. Barberena, R., 2015. Cueva Huenul 1 Archaeological Site (Northwestern Patagonia, Argentina): Initial Colonization and mid-Holocene Demographic Retraction. Lat. Am. Antiq. 26, 304-318.

Barberena, R., Borrazzo, K., Rughini, A., Romero, G., Pompei, M.P., Llano, C., de Porras, M.E., Durán, V., Stern, C.R., Re, A., Estrella, D., Forasiepi, A., Fernández, F.J., Chidiak, M., Acuña, L., Gasco, A., Quiroga, M.N., 2015. Perspectivas arqueológicas para Patagonia septentrional: sitio Cueva Huenul 1 (Provincia del Neuquén, Argentina). Magallania 43, 1-27.

Barberena, R., Hajduk, A., Gil, A., Neme, G., Durán, V., Glascock, M., Giesso, M., Borrazzo, K., Pompei, P., Salgán, L., Cortegoso, V., Villarosa, G., Rughini, A., 2011. Obsidian in the south-central Andes: geological, geochemical, and archaeological assessment of north Patagonian Sources (Argentina). Quatern. Int. 245, 25-36. Bettinger, R.L., Madsen, D.B., Elston, R.G., 1994. Prehistoric Settlement Categories and Settlement Systems in the Alashan Desert of Inner Mongolia, PRC. J. Anthropol. Archaeol. 13, 74-101.

Binford, L.R., 1980. Willow Smoke and Dog's Tails: Hunter-Gatherer Settlement Systems and Archaeological Site Formation. Am. Antiq. 45, 4-20.

Cabrera, A., Weinberg, R.F., Wright, H.M.N., Zlotnik, S., Cas, R.A.F., 2010. Melt fracturing and healing: A mechanism for degassing and origin of silicic obsidian. Geology 39, 67-70. 
Chiapella, J., Ezcurra, C., 1999. La flora del Parque Provincial Tromen, Provincia de Neuquén, Argentina. Multequina 8, 51-60.

Civalero, M.T., Franco, N.V., 2003. Early human occupations in Western Santa Cruz Province, Southernmost South America. Quatern. Int. 109, 77-86.

Clapperton, C., 1993. Quaternary Geology and Geomorphology of South America. Elsevier, Amsterdam.

Cortegoso, V., Barberena, R., Durán, V., Lucero, G., 2016. Geographic vectors of human mobility in the Andes (34-36 $\left.{ }^{\circ} \mathrm{S}\right)$ : comparative analysis of 'minor' obsidian sources. Quatern. Int. 422, 81-92.

Cortegoso, V, Neme, G., Giesso, M., Durán, V., Gil, A., 2012. El uso de la obsidiana en el sur de Mendoza. In: Neme, G., Gil, A. (Eds.), Paleoecología humana en el Sur de Mendoza. Sociedad Argentina de Antropología, Buenos Aires, pp. 181-211.

De Francesco, A., Durán, V., Bloise, A., Neme, G., 2006. Caracterización y procedencia de obsidianas de sitios arqueológicos del área natural protegida Laguna del Diamante (Mendoza Argentina) con metodología no destructiva por fluorescencia de rayos (XRF). Anales de Arqueología y Etnología 61, 53-67.

Durán, V., De Francesco, A.M., Cortegoso, V., Neme, G., Cornejo, L., Bocci, M., 2012. Caracterización y procedencia de obsidianas de sitios arqueológicos del Centro Oeste de Argentina y Centro de Chile con metodología no destructiva por Fluorescencia de Rayos X (XRF). Intersecciones Antropol. 13, 423-437.

Durán, V., Giesso, M., Glascock, M.D., Neme, G., Gil, A., Sanhueza, L., 2004. Estudio de fuentes de aprovisionamiento y redes de distribución de obsidiana durante el Holoceno Tardío en el sur de Mendoza (Argentina). Estudios Atacameños 28, 25-43. Eerkens, J.W., King, J., Glascock, M.D., 2002. Artifact size and chemical sourcing: Studying the potential biases of selecting large artifacts for analysis. Society of California Archaeology Newsletter 36, 25-29.

Ericson, J.E. 1984. Toward the analysis of lithic production systems. In: Ericson, J.E., Purdy, B.A. Prehistoric quarries and lithic production. Cambridge, Cambridge University Press, pp. 1-10.

Fernandez, M.V., Barberena, R., Rughini, A., Borrazzo, K., MacDonald, B., Glascock, M.D., in prep. Geoarcheology and spatial structure of an obsidian source: The case of Laguna del Maule (Argentina-Chile). Ms. 
Folguera, A., Bottesi, G., Zapata, T., Ramos, V.A., 2008. Crustal collapse in the Andean back arc since $2 \mathrm{Ma}$ : Tromen volcanic plateau, Southern Central Andes (36² $\left.40^{\prime}-37^{\circ} 30^{\prime} \mathrm{S}\right)$. Tectonophysics 459, 140-160.

Fierstein, J., Sruoga, P., Amigo, A., Elissondo, M., Rosas, M., 2014. Tephra in Argentina establishes postglacial eruptive history of Laguna del Maule volcanic field in Chile: 36 silicic eruptions in $14 \mathrm{Ka}$. In: Actas del XIX Congreso Geológico Argentino, Volcanes Activos, Córdoba, pp. 23-17.

Freundt, A., Wilson, C.J.N., Carey, S.N., 2000. Ignimbrites and block-and-ash flow deposits. In: Sigurdsson, H., Houghton, B.F., McNutt, S.R., Rymer, H., Stix, J. (Eds.), Encyclopedia of Volcanoes. Academic Press, New York, pp. 581-603.

Garreaud, R.D., Vuille, M., Compagnucci, R., Marengo, J., 2009. Present-day South America climate. Palaeogeogr. Palaeoecl. 281, 180-195.

Garvey, R., 2012. El uso de la hidratación de obsidianas en el sur de Mendoza, Argentina. In: Neme, G., Gil, A. (Eds.), Paleoecología humana en el Sur de Mendoza. Sociedad Argentina de Antropología, Buenos Aires, pp. 213-227.

Giesso, M., Durán, V., Neme, G., Glascock, M.D., Cortegoso, V., Gil, A., Sanhueza, L., 2011. A study of obsidian source usage in the central Andes of Argentina and Chile. Archaeometry 53, 1-21.

Glascock, M.D., 2002. Obsidian provenance research in the Americas. Accounts of Chem. Res. 35, 611-617.

Glascock, M.D., Ferguson, J.E., 2012. Report on the analysis of obsidian source samples by multiple analytical methods. Archaeometry Lab, University of MissouriColumbia.

Glascock, M.D., Speakman, R.J., Burger, R.L., 2007. Sources of Archaeological Obsidian in Peru: Descriptions and Geochemistry. In: Glascock, M.D., Speakman, R.J., Popelka-Filcoff, R.S., (Eds.), Archaeological Chemistry. Analytical Techniques and Archaeological Interpretation. ACS Symposium Series 968, American Chemical Society, Washington DC, pp. 522-552.

Groeber, P., 1946. Observaciones geológicas a lo largo del meridiano 70. 1. Hoja Chos Malal. Revista de la Asociación Geológica Argentina I, 177-211.

Hildreth, W., Godoy, E., Fierstein, J., Singer, B., 2009. Laguna del Maule volcanic field: Eruptive history of a Quaternary basalt-to-rhyolite distributed volcanic field on the Andean range crest in Central Chile. Boletín 63. Servicio Nacional de Minería y Geología, Chile. 
Holdaway, S., Wandsnider, L.A., 2006. Temporal Scales and Archaeological Landscapes from the Eastern Desert of Australia and Intermontane North America. In: Lock, G., Molyneaux, B. (Eds.), Confronting Scale in Archaeology. Issues of Theory and Practice. Springer, New York, pp. 183-202.

Hughes, R.L., 1998. On Reliability, Validity, and Scale in Obsidian Sourcing Research. In: Ramenofsky, A.F., Steffen, A. (Eds.), Unit Issues in Archaeology. Measuring Time, Space, and Material. University of Utah Press, Salt Lake City, pp. 103-114. Jones, G.T., Beck, C., Jones, E.E., Hughes, R., 2003. Lithic Source Use and Paleoarchaic Foraging Territories in the Great Basin. Am. Antiq. 68, 5-38. Kay, S., Burns, W., Copeland,P., Mancilla, O., 2006. Upper Cretaceous to Holocene magmatism and evidence for transient Miocene shallowing of the Andean subduction zone under the northern Neuquén Basin. In: Kay, S., Ramos, V. (Eds.), Evolution of an Andean margin. A tectonic and magmatic view from the Andes to the Neuquén Basin $\left(35^{\circ}-39^{\circ}\right.$ S lat). Geological Society of America Special Paper 407, New York, pp. 1960.

Kelly, R.L., 1995. The Foraging Spectrum. Diversity in Hunter-Gatherers Lifeways. Smithsonian Institution, Washington DC.

Kelly, R.L., 2011. Obsidian in the Carson Desert: Mobility or Trade? In: Hughes, R.E. (Ed.), Perspectives on Prehistoric Trade and Exchange in California and the Great Basin. University of Utah Press, Salt Lake City, pp. 189-200.

Kuhn, S., 2004. Upper Paleolithic raw material economies at Ücagizli cave, Turkey. J. Anthrop. Archaeol. 23, 431-448.

León, R.J.C., Bran, D., Collantes, M., Paruelo, J.M., Soriano, A., 1998. Grandes unidades de vegetación de la Patagonia extra andina. Ecología Austral 8, 125-144. Marlowe, F.W., 2005. Hunter-Gatherers and Human Evolution. Evol. Anthropol. 14, $54-67$.

Millhauser, J.K., Rodríguez-Alegría, E., Glascock, M.D. 2011. Testing the accuracy of portable X-ray fluorescence to study Aztec and Colonial obsidian supply at Xaltocan, Mexico. J. Archaeol. Sci. 38, 3141-3152.

Narciso, V., Santamaría, G., Zanettini, J.C.M., 2004. Hoja Geológica 3769-I, Barrancas. Provincias de Mendoza y Neuquén. Boletín 253, Instituto de Geología y Recursos Minerales, Servicio Geológico Minero Argentino, Buenos Aires. 
Neme, G.A., Gil, A.F., Garvey, R., Llano, C.L., Zangrando, A., Franchetti, F., De Francesco, C., Michieli, C.T., 2011. El registro arqueológico de la Gruta de El Manzano y sus implicancias para la arqueología de Nordpatagonia. Magallania 39, 243-265. Pérez, A.E., Giesso, M., Glascock, M.D., 2015. Fuentes de aprovisionamiento y uso de obsidianas del ámbito boscoso y lacustre andino norpatagónico (Provincia del Neuquén, Argentina). Intersecciones Antropol., Special Volume 2, 17-26.

Pintar, E., Martínez, J.G., Aschero, C.A., Glascock, M.D. 2016. Obsidian use and mobility during the Early and Middle Holocene in the Salt Puna, NW Argentina. Quatern. Int. 422, 93-108.

Rademaker, K., Glascock, M.D., Kaiser, B., Gibson, D., Lux, D.R., Yates, M.G., 2013. Multi-technique geochemical characterization of the Alca obsidian source, Peruvian Andes. Geology 41, 779-782.

Renfrew, C., 1977.Alternate Models for Exchange and Spatial Distribution. In: Earle, T.K. (Ed.). Exchange Systems in Prehistory. Academic Press, New York, pp. 71-89. Romero, G., A. Re. 2014. Representaciones rupestres del noreste de Neuquén (Patagonia septentrional). Primeras tendencias espaciales y temporales. Comechingonia $18,73-92$.

Romero Villanueva, G., Barberena, R., Rughini, A., Garvey, R., Llano, C., Fernández, M.V., 2017. Archaeology of Cueva Yagui site, northwestern Patagonia (Neuquén Province, Argentina). In preparation.

Rughini, A.A., 2016. Tecnología lítica del noreste de Neuquén. Análisis del sitio Cueva Huenul 1. Departamento Pehuenches, localidad Barrancas, provincia del Neuquén, Argentina. Licenciature Thesis. Facultad de Filosofia y Letras, Universidad de Buenos Aires, Buenos Aires.

Salgán, L., Garvey, R., Neme, G., Gil, A., Giesso, M., Glascock, M.D., Durán, V., 2015. Las Cargas: Characterization and prehistoric use of a southern Andean obsidian source. Geoarchaeology 30, 139-150.

Salgán, L., Gil, A., Neme, G., 2012. Obsidianas en la Payunia (sur de Mendoza, Argentina): Patrones de distribución e implicancias en la ocupación regional. Magallania 40, 263-277.

Salgán, L., Gil, A., Neme, G., 2014. Movilidad, aprovisionamiento y uso de obsidiana en El Payén, sur de la provincia de Mendoza, Argentina. Comechingonia 18, 33-50. 
Seelenfreund, A., Rees, C., Bird, R., Bailey, G., Bárcena, R., Durán, V., 1996. Trace element analysis of obsidian sources and artifacts of Central Chile (Maule River Basin) and Western Argentina (Colorado River). Lat. Am. Antiq. 7, 7-20.

Shackley, M.S., 1992. The Upper Gila River gravels as an archaeological obsidian source region: Implications for models of exchange and interaction. Geoarchaeology 7 , $315-326$.

Shackley, M.S., 2005. Obsidian: Geology and Archaeology in the North American Southwest. University of Arizona Press, Tucson.

Shackley, M.S., 2011. An introduction to x-ray fluorescence (XRF) Analysis in Archaeology. In: Shackley, M.S. (Ed.), X-Ray Fluorescence Spectrometry (XRF) in Geoarchaeology. Springer, New York, pp. 7-44.

Shelley, P.H., 1993. A Geoarchaeological Approach to the Analysis of Secondary Lithic Deposits. Geoarchaeology 8, 59-72.

Shott, M. J. 2003. Chaîne Opératoire and Reduction Sequence. Lithic Technology 28, 95-105.

Smith, G. M., 2011. Shifting stones and changing homes: Using toolstone ratios to consider relative occupation span in the northwestern Great Basin. J. Archaeol. Sci. 38, 461-469.

Stern, C.R., 2004. Active Andean volcanism: its geologic and tectonic setting. Rev. Geol. Chile 31, 161-206.

Stern, C.R., Pereda, I., Aguerre, A.M., 2012. Multiple primary and secondary sources for chemically similar obsidians from the area of Portada Covunco, West-central Neuquén, Argentina. Archaeometry 54, 442-453.

Stevenson, C.M., Rogers, A.K. 2016. Calibrations for the determination of water species in bulk and hydrated obsidian by infrared photoacoustic spectroscopy. J. Archaeol. Sci. Reports 6, 109-114.

Surovell, T.A., 2009. Towards a Behavioral Ecology of Lithic Technology. Cases from Paleoindian Archaeology. University of Arizona Press, Tucson.

Torrence, R., Kelloway, S., White, P., 2013. Stemmed Tools, Social Interaction, and Voyaging in Early-Mid Holocene Papua New Guinea. J. Island \& Coastal Archaeol. 8, $278-310$.

Veth, P., 2005. Cycles of aridity and human mobility: risk minimization among Late Pleistocene foragers of the Western Desert, Australia. In: Veth, P., Smith, M., Hiscock, 
P. (Eds.), Desert Peoples. Archaeological Perspectives. Blackwell Publishing, London, pp. 100-115.

Zöllner, W., Amos, A.J., 1973. Descripción Geológica de la Hoja 32b, Chos Malal.

Boletín 143, Servicio Nacional Minero Geológico, Buenos Aires. 


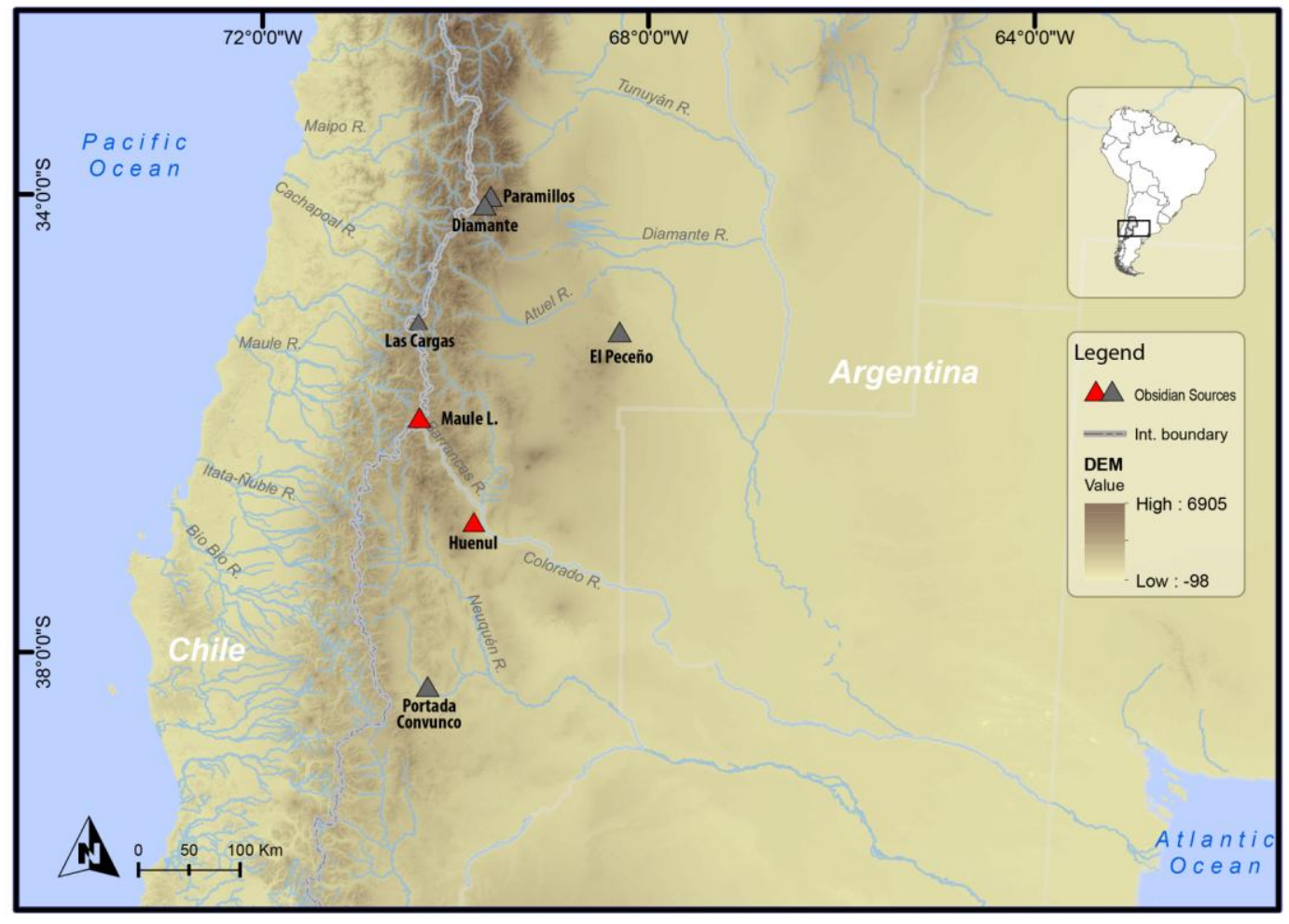

Fig. 1 


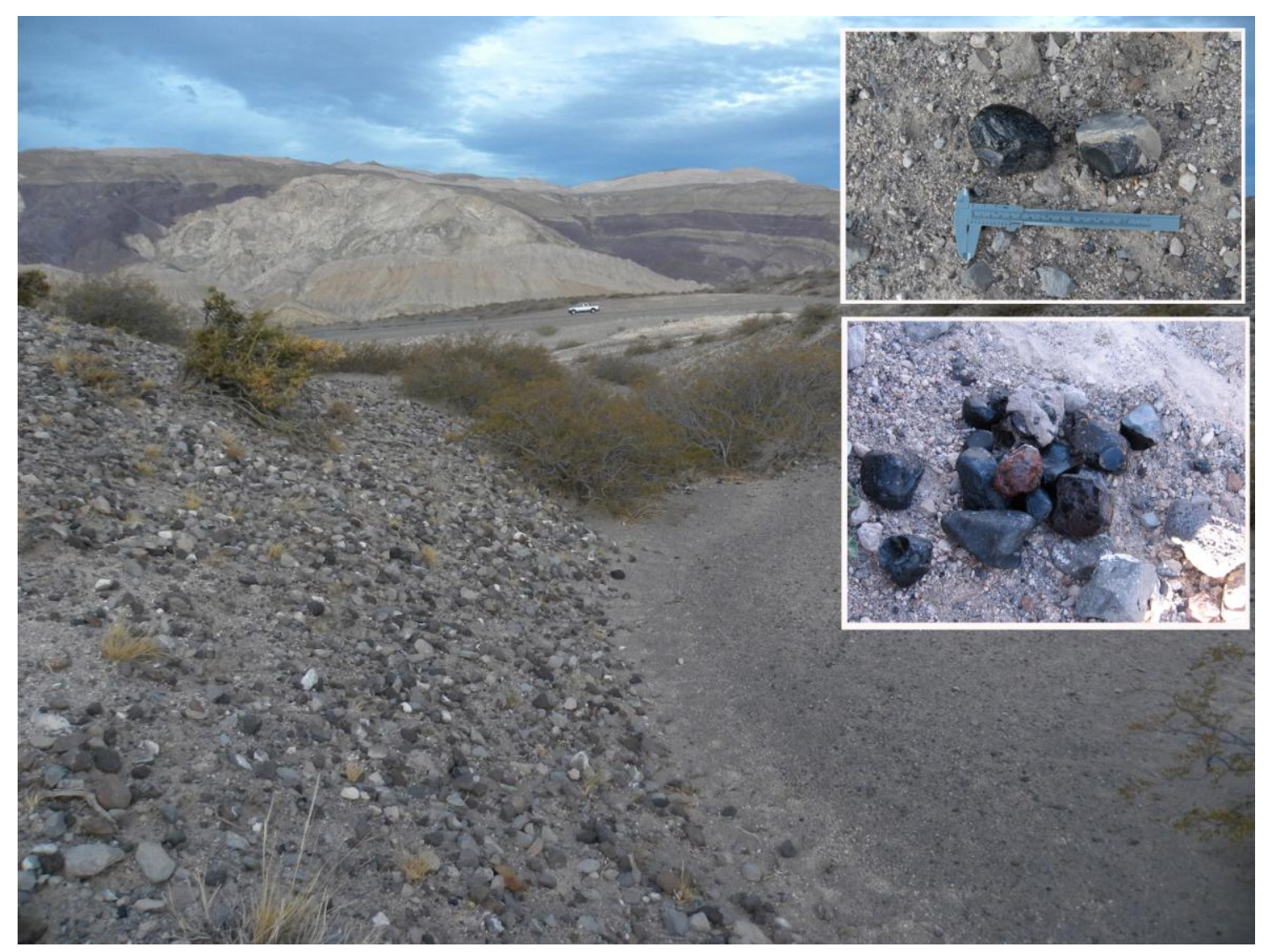

Fig. 2 


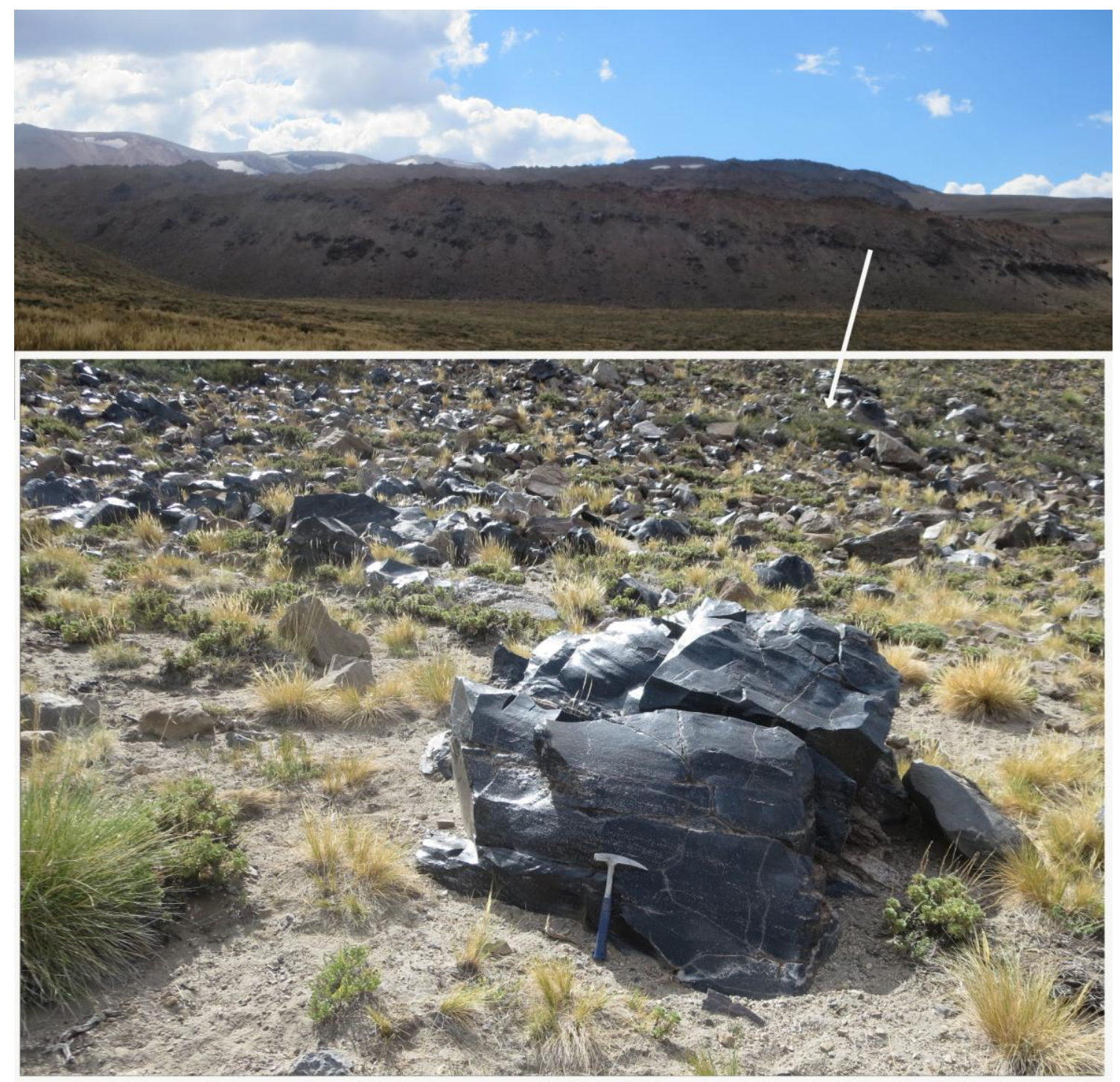

Fig. 3 


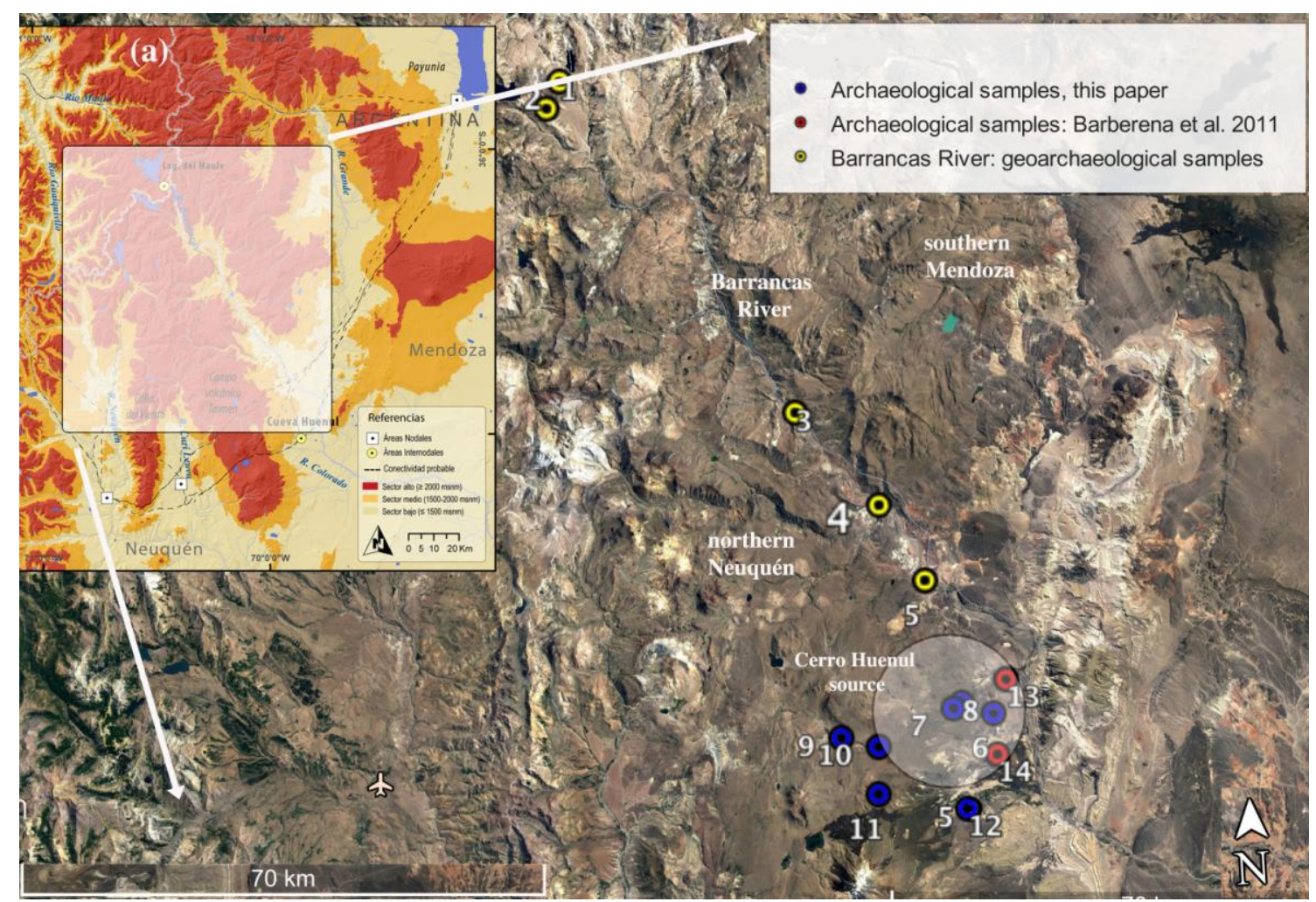

Fig. 4 


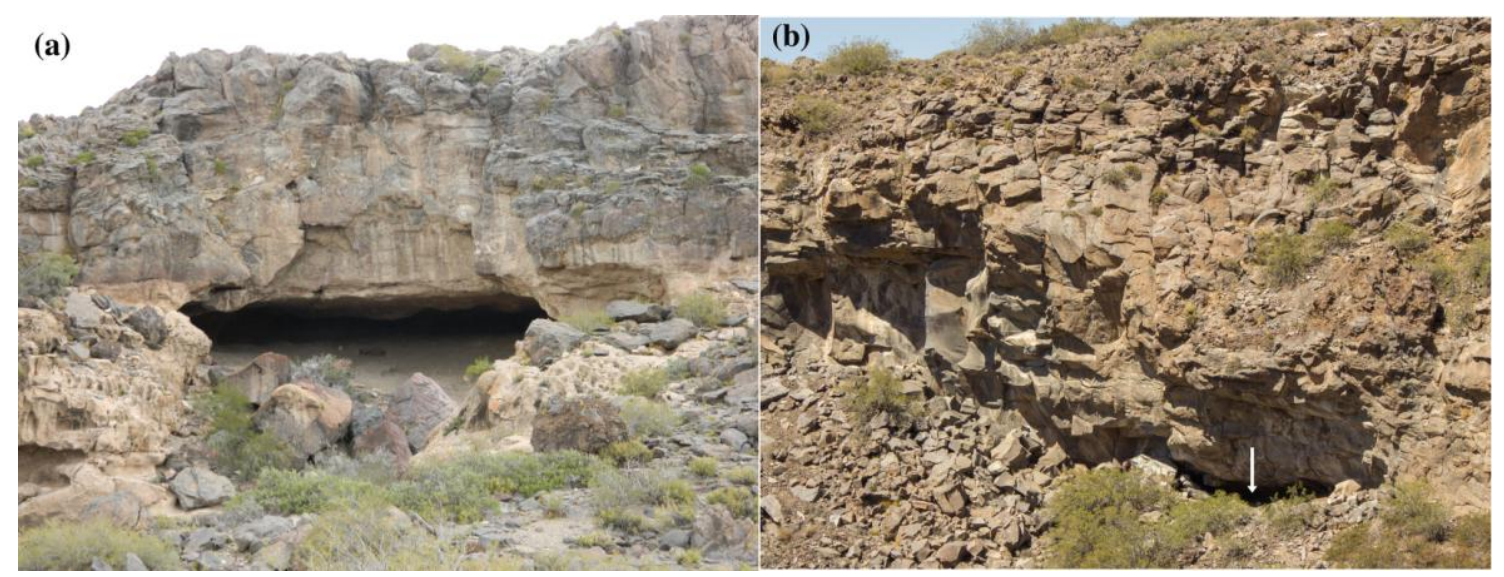

Fig. 5 


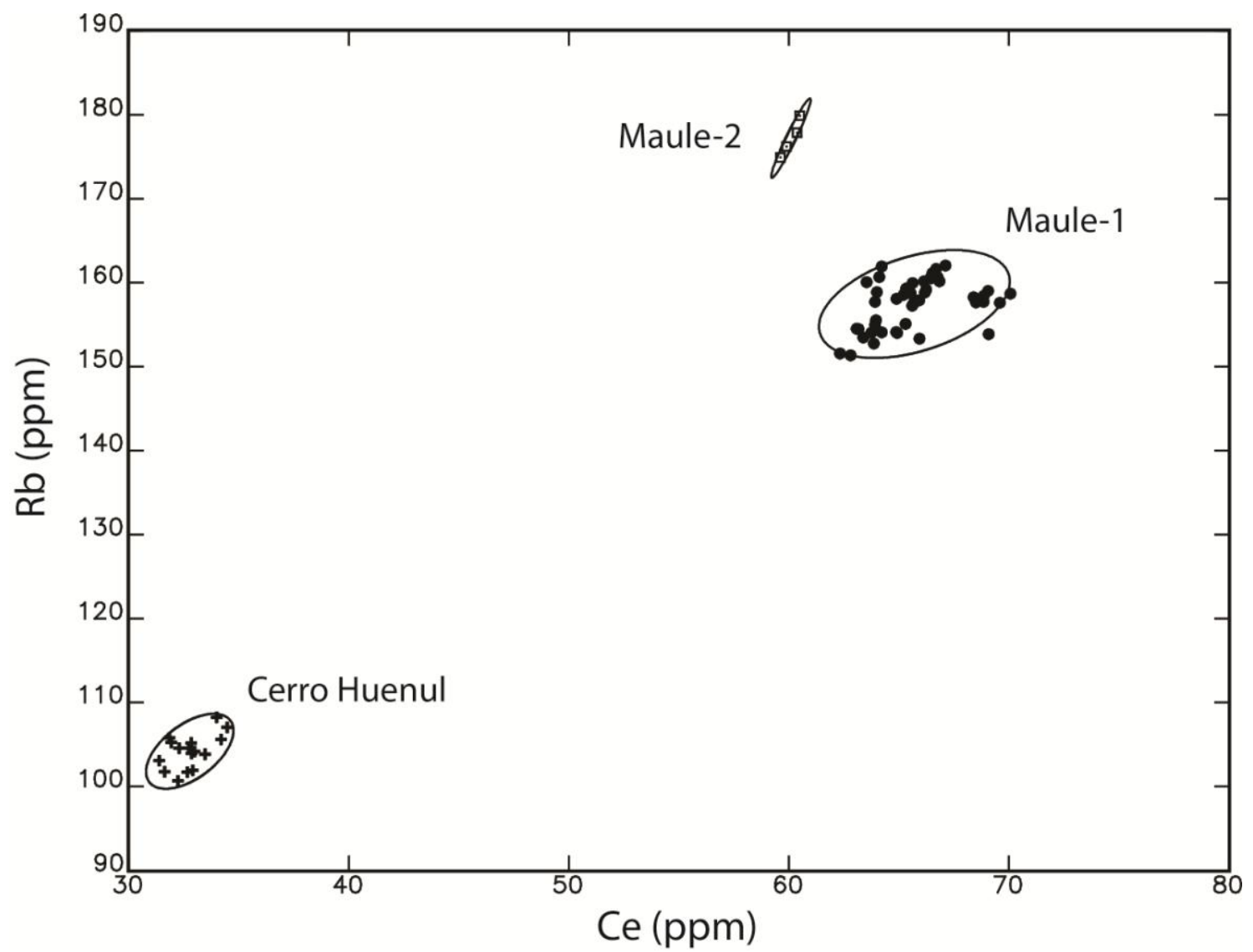

Fig. 6 
a)

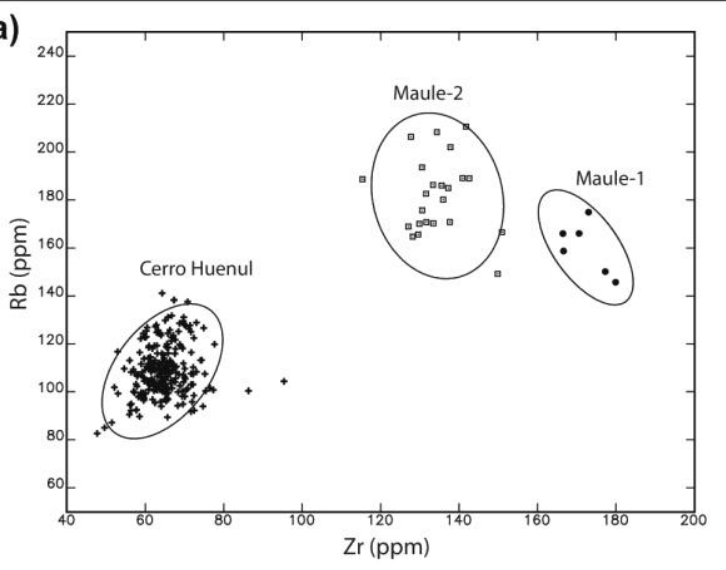

b)

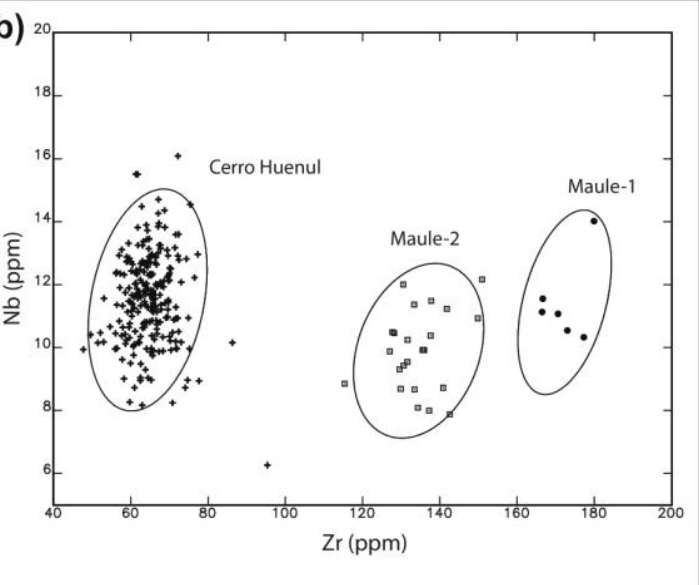

Fig. 7 